Review

\title{
Cementitious building materials reinforced with vegetable fibres: A review
}

\author{
Fernando Pacheco-Torgal ${ }^{\mathrm{a}, *}$, Said Jalali ${ }^{\mathrm{b}, 1}$ \\ a University of Minho, C-TAC Research Unit, 4800 Guimarães, Portugal \\ ${ }^{\mathrm{b}}$ University of Minho, Department of Civil Engineering, 4800 Guimarães, Portugal
}

\section{A R T I C L E I N F O}

\section{Article history:}

Received 7 April 2010

Received in revised form 23 July 2010

Accepted 28 July 2010

Available online $\mathrm{xxxx}$

\section{Keywords:}

Cementitious composites

Vegetable fibres

Properties

Durability

\begin{abstract}
A B S T R A C T
The construction industry is responsible for the depletion of large amounts of nonrenewable resources. This activity generates not only millions of tons of mineral waste but also millions of tons of carbon dioxide gas emissions. Therefore, research about building materials based on renewable resources like vegetable fibres is needed. This paper discusses the use of vegetable fibres as reinforcement in cement based materials. It includes fibre characteristics, properties and the description of the treatments that improve their performance; it covers the compatibility between the fibres and the cement matrix and also how the fibres influence cement properties. It also includes the properties and durability performance of cementitious materials reinforced with vegetable fibres. Furthermore future research trends are also suggested.
\end{abstract}

(c) 2010 Elsevier Ltd. All rights reserved.

\section{Contents}

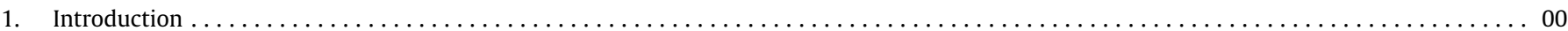

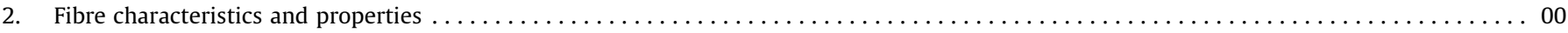

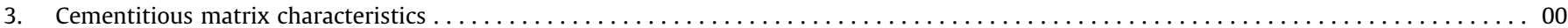

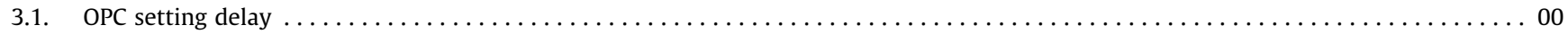

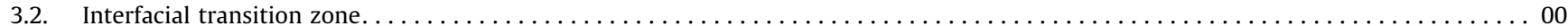

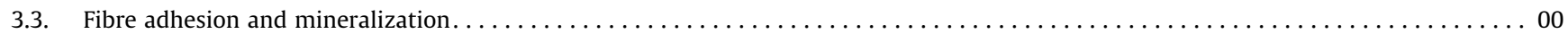

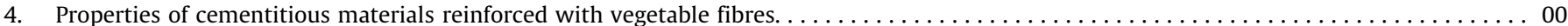

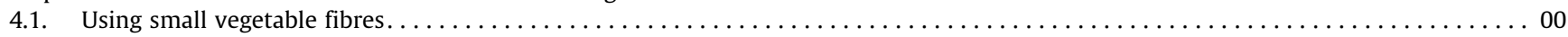

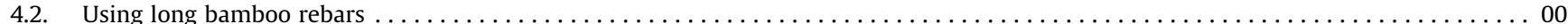

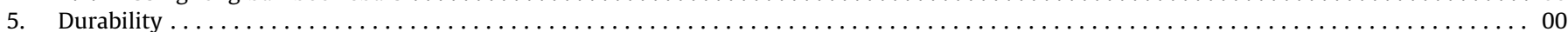

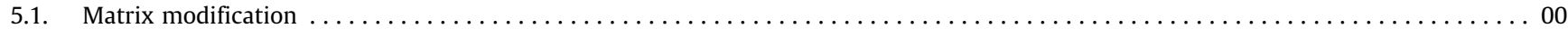

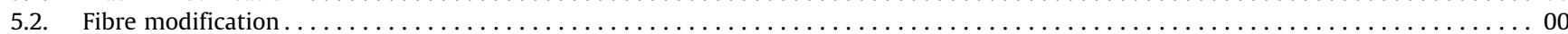

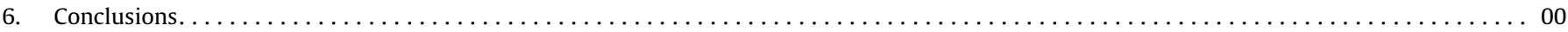

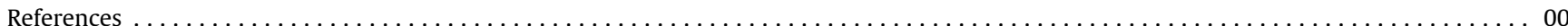

\section{Introduction}

The construction industry is one of the major and most active sectors in Europe. It represents 28\% and 7\% of employment respectively, of the industry and of all the European economy. Unfortunately this industry is also responsible for the depletion of large amounts of nonrenewable resources and for $30 \%$ of carbon dioxide

\footnotetext{
* Corresponding author. Tel.: +351 253 510200; fax: +351 253510213.

E-mail addresses: torgal@civil.uminho.pt (F. Pacheco-Torgal), said@civil.uminho.pt (S. Jalali).

1 Tel.: +351253 510200; fax: +351253510213
}

gas emissions. This is particularly serious in the current context of climate change caused by carbon dioxide emissions worldwide, leading to a rise in the sea level [1] and being responsible for a meltdown in the world economy [2]. In order to achieve a more sustainable construction industry, the European Union recently established that in a medium term raw materials consumption must be reduced by $30 \%$ and that waste production in this sector must be cut down by $40 \%$. The use of renewable resources by the construction industry will help to achieve a more sustainable consumption pattern of building materials. Concrete is the most used material on Earth and it is known for its high compressive strength and low tensile strength. The combined use of regular concrete and

0950-0618/\$ - see front matter (c) 2010 Elsevier Ltd. All rights reserved. doi:10.1016/j.conbuildmat.2010.07.024 
steel reinforced bars is needed to overcome that disadvantage leading to a material with good compressive and tensile strengths but also with a long post-crack deformation (strain softening). Unfortunately reinforced concrete has a high permeability that allows water and other aggressive elements to penetrate, leading to carbonation and chloride ion attack resulting in corrosion problems $[3,4]$. Steel rebar corrosion is in fact the main reason for infrastructure deterioration. Gjorv [5] mentioned a study of Norway OPC bridges indicating that $25 \%$ of those built after 1970 presented corrosion problems. Another author [6] mentioned that $40 \%$ of the 600,000 bridges in the US were affected by corrosion problems and estimated in 50 billion dollars the repairing operations cost. Concrete durability is environmental related. If we were able to increase the life time of concrete from 50 to 500 years, its environmental impact decreases 10 times [7]. Since an average of $200 \mathrm{~kg}$ of steel rebar is used for each cubic meter of concrete structure it is clear that the replacement of reinforced steel rebar by vegetable fibres is a major step to achieve a more sustainable construction. On the other hand, reinforced steel is a highly expensive material, has high energy consumption and comes from a nonrenewable resource. Natural fibres are a renewable resource and are available almost all over the world [8]. Furthermore, due to cancer health risks $[9,10]$ the Directive $83 / 477 /$ EEC and amending Directives 91/382/EEC, 98/24/EC; 2003/18/EC and 2007/30/EC forbid the production of cementitious products based on fibre silicates (asbestos). Mineral fibres are now being replaced by synthetic fibres like polyvinyl alcohol (PVA) and polypropylene to produce fibre-cement products using the Hatscheck process [11]. However, production of PVA and polypropylene needs phenol compounds as antioxidants and amines as ultraviolet stabilizers and other to act as flame retardant which is not the path to more sustainable materials [12]. This represents another large opportunity in the field of vegetable fibres cement based materials because they are as stronger as synthetic fibres, cost-effective and above all environmental friendly. Therefore, to promote the use of cementitious building materials reinforced with vegetable fibres could be a way to achieve a more sustainable construction. This paper deals with the subject of natural fibre reinforced cementitious materials by reviewing previously published work. The review is divided into six sections: 1 - Introduction, 2 - fibre characteristics and properties, 3 - cementitious matrix characteristics, 4 - properties of cementitious materials reinforced with vegetable fibres, 5 durability, 6 - conclusions.

\section{Fibre characteristics and properties}

Vegetable fibres are natural composites with a cellular structure. Different proportions of cellulose, hemicellulose and lignin constitute the different layers. Cellulose is a polymer containing glucose units. Hemicellulose is a polymer made of various polysaccharides. As for lignin it is an amorphous and heterogeneous mixture of aromatic polymers and phenyl propane monomers [13]. Different fibres have different compositions (Table 1) therefore it is expected that their behaviour inside a cement matrix could differ between them. Natural fibres have a high tensile strength and they have low modulus of elasticity (Table 2). Even so, their tensile performance can stand in a favourable manner with synthetic ones. One of the disadvantages of using natural fibres is that they have a high variation on their properties which could lead to unpredictable concrete properties $[17,18]$. Pre-treatment of natural fibbers was found to increase concrete performance. Pulping is one of the fibre treatments that improve fibre adhesion to the cement matrix and also resistance to alkaline attack [19]. Pulping can be obtained by a chemical process (kraft) or a mechanical one. Table 3 presents some pulping conditions for sisal and banana fibres. Some chemical treatments lead to a higher mechanical perfor- mance than others [20]. The pulping process through mechanical conditions has a lower cost (around half) when compared to the use of chemical conditions and has no need for effluent treatments [21]. Some authors suggest the use of organofunctional silane coupling agents to reduce the hydrophilic behaviour of vegetable fibres [22,23]. But recently Joaquim et al. [24] compared the performance of cementitious composites reinforced by kraft pulp sisal fibres and by sisal fibres modified by the organosolv process. They found out that the best mechanical performance was achieved by the composites with kraft pulp fibres. Arsene et al. [25] suggests that using a pyrolisis process can increase the fibre strength by a factor of three.

\section{Cementitious matrix characteristics}

\subsection{OPC setting delay}

Savastano et al. [26] mentioned that acid compounds released from natural fibres reduce the setting time of the cement matrix. Fibre sugar components, hemicellulose and lignin can contribute to prevent cement hydration $[27,28]$. According to Sedan et al. [29], fibre inclusion can reduce the delay of setting by $45 \mathrm{~min}$. The explanation relies on the fact that pectin (a fibre component) can fix calcium preventing the formation of CSH structures.

\subsection{Interfacial transition zone}

The interfacial transition zone between concrete and natural fibres is porous, cracked and rich in calcium hydroxide crystal [30]. Those authors reported a $200 \mu \mathrm{m}$ thick at 180 days. On the contrary others [31] reported that using vacuum dewatering and high pressure applied after molding led to a dense ITZ (Fig. 1a) also reporting fibres without hydration products (Fig. 1b).

Table 1

Composition of vegetable fibres [14].

\begin{tabular}{llllll}
\hline Fiber & $\begin{array}{l}\text { Lignin } \\
(\%)\end{array}$ & $\begin{array}{l}\text { Cellulose } \\
(\%)\end{array}$ & $\begin{array}{l}\text { Hemicellulose } \\
(\%)\end{array}$ & $\begin{array}{l}\text { Extractives } \\
(\%)\end{array}$ & $\begin{array}{l}\text { Ash } \\
(\%)\end{array}$ \\
\hline Bagasse & 21.8 & 41.7 & 28.00 & 4.00 & 3.50 \\
Banana leaf & 24.84 & 25.65 & 17.04 & 9.84 & 7.02 \\
$\begin{array}{c}\text { Banana } \\
\text { trunk }\end{array}$ & 15.07 & 31.48 & 14.98 & 4.46 & 8.65 \\
$\begin{array}{c}\text { Coconut } \\
\text { coir }\end{array}$ & 46.48 & 21.46 & 12.36 & 8.77 & 1.05 \\
$\begin{array}{c}\text { Coconut } \\
\text { tissue }\end{array}$ & 29.7 & 31.05 & 19.22 & 1.74 & 8.39 \\
$\begin{array}{c}\text { Eucalyptus } \\
\text { Sisal }\end{array}$ & 25.4 & 41.57 & 32.56 & 8.20 & 0.22 \\
\hline
\end{tabular}

Table 2

Properties of natural and synthetic fibres [14]

\begin{tabular}{lllll}
\hline Properties & $\begin{array}{l}\text { Specific } \\
\text { gravity }(\mathrm{kg} / \\
\left.\mathrm{m}^{3}\right)\end{array}$ & $\begin{array}{l}\text { Water } \\
\text { absorption } \\
(\%)\end{array}$ & $\begin{array}{l}\text { Tensile } \\
\text { strength } \\
(\mathrm{MPa})\end{array}$ & $\begin{array}{l}\text { Modulus of } \\
\text { elasticity } \\
(\mathrm{GPa})\end{array}$ \\
\hline Sisal & 1370 & 110 & $347-378$ & 15.2 \\
Coconut & 1177 & 93.8 & $95-118$ & 2.8 \\
Bamboo & 1158 & 145 & $73-505$ & $10-40$ \\
Hemp & 1500 & $85-105$ & 900 & 34 \\
Caesar weed & 1409 & 182 & $300-500$ & $10-40$ \\
Banana & 1031 & 407 & 384 & $20-51$ \\
$\begin{array}{l}\text { Piassava palm } \\
\text { Date palm }\end{array}$ & 1054 & $34-108$ & 143 & 5.6 \\
$\quad 1300-1450$ & $60-84$ & $70-170$ & $2.5-4$ \\
$\begin{array}{l}\text { Polypropylene } \\
\text { PVA F45 [16] }\end{array}$ & 913 & - & 250 & 2.0 \\
\hline
\end{tabular}


Table 3

Sisal and banana kraft pulping conditions [19].

\begin{tabular}{lll}
\hline Parameter & Sisal & Banana \\
\hline $\begin{array}{l}\text { Active alkali }\left(\mathrm{as} \mathrm{Na}_{2} \mathrm{O}\right) \\
\quad \text { \%) }\end{array}$ & 9 & 10 \\
$\begin{array}{c}\text { Sulphidity }\left(\text { as } \mathrm{Na}_{2} \mathrm{O}\right) \\
(\%)\end{array}$ & 25 & 25 \\
$\begin{array}{l}\text { Liquor/fibre ratio } \\
\text { Temperature }\left({ }^{\circ} \mathrm{C}\right)\end{array}$ & $5: 1$ & $7: 1$ \\
Digestion time & 170 & 170 \\
& $\sim 75$ min to temperature & $\sim 85$ min to temperature \\
Total yield $(\% \mathrm{w} / \mathrm{w})$ & 120 min cook & 120 min cook \\
Screened yield $(\% \mathrm{w} / \mathrm{w})$ & 45.5 & 45.9 \\
\hline
\end{tabular}

\subsection{Fibre adhesion and mineralization}

The use of water-repellents also leads to a good bond between natural fibres and concrete [32]. The mechanical treatment of the fibres also improves the bonding between the fibre and cement [33]. Alkaline treatment of fibres improves their strength and also fibre-matrix adhesion [29]. Tonoli et al. [34] compared cement composites with vegetable fibres previously submitted to surface modification with methacryloxypropyltri-methoxysilane (MPTS) and aminopropyltri-ethoxysilane (APTS). The results of composites with fibres modified by MPTS show fibres free from cement hydration products while APTS based fibres presented accelerated mineralization (Fig. 2) which leads to higher embrittlement behaviour of cement composites.

\section{Properties of cementitious materials reinforced with vegetable fibres}

\subsection{Using small vegetable fibres}

Some authors [35] found out that the use of $0.2 \%$ volume fraction of $25 \mathrm{~mm}$ sisal fibres leads to free plastic shrinkage reduction. The combined use of coconut and sisal short fibres seem to delayed restrained plastic shrinkage controlling crack development at early ages. As for the mechanical performance of natural fibre concrete Al-Oraimi and Seibi [36] reported that using a low percentage of natural fibres improved the mechanical properties and the impact resistance of concrete and had similar performance when compared to synthetic fibre concrete. Other authors [37] reported that fibre inclusion increases impact resistance 3-18 times higher than when no fibres were used. The use of small volumes $(0.6-0.8 \%)$ of Arenga pinata fibres show capacity to increase the toughness in cement based composites [38]. Hemp fibre reinforced concrete leads to an increase of flexural toughness by $144 \%$, and an increase in flexural toughness index by $214 \%$ [39]. Reis [40] shows that the mechanical performance of fibre polymer concrete depends on the type of fibre. Being that coconut and sugar cane bagasse fibre increases polymer concrete fracture toughness but banana pseudo stem fibre does not. The use of coconut fibres shows even better flexural than synthetic fibres (glass and carbon). Li et al. [41] report that flexural toughness and flexural toughness index of cementitious composites with coir fibre increased by more than 10 times. Silva et al. [42] studied the addition of sisal fibres to concrete and reported that compressive strength was lower than concrete samples without the fibres. The explanation for that behaviour seems to be related to low concrete workability. Savastano et al. [43] compared the mechanical performance of cement composites reinforced with sisal, banana and eucalyptus fibres. Sisal and banana fibres with higher lengths $(1.65 \mathrm{~mm}$ and $1.95 \mathrm{~mm})$ than those of the eucalyptus $(0.66 \mathrm{~mm})$ showed a more stable fracture behaviour which confirm that fibre length influences the process by which (a)

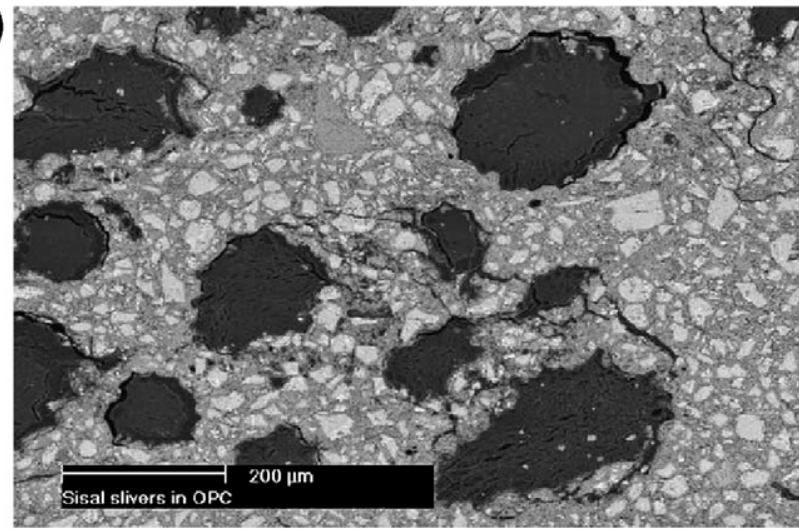

(b)

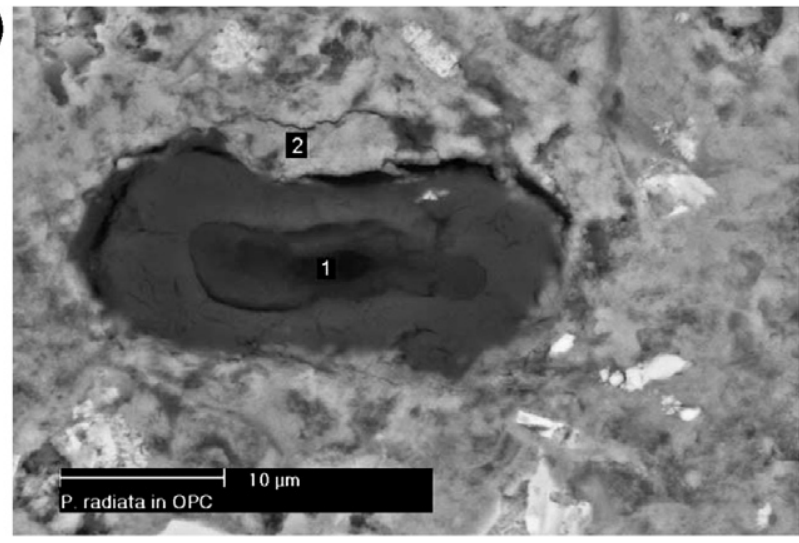

Fig. 1. (a) BSE image of sisal fibres in cement matrix with dense ITZ; (b) EDS analysis on Pinus radiata fibre lumen (spot 1 ) revealed that no mineralization due to the presence of hydration products was detected [31].

load is transferred from the matrix to the fibres. Other authors [44] tested cement composites reinforced by long sisal fibres placed at the full length of a steel mold in five layers (mortar/fibres/mortar). These composites reach ultimate strengths of 12 and $25 \mathrm{MPa}$ under tension and bending loads. The vegetable type also influences the performance of cement composites [45], so much so that eucalyptus based ones present improved mechanical performance after 200 ageing cycles than the ones that are pinus based. The explanation points to a better distribution of vegetable particles in the cement matrix (Fig. 3).

\subsection{Using long bamboo rebars}

Khare [46] tested several concrete beams and reported that bamboo has potential to be used as substitute for steel reinforcement (Fig. 4). This author reported that the ultimate load capacity of bamboo was about 35\% of the equivalent reinforced steel concrete beams. Fig. 5 shows a concrete sample were fibre imprints are visible as an example for low adhesion between cement matrix and bamboo. Others mentioned just $25 \%$ of the equivalent reinforced steel concrete beams ultimate load capacity [47]. Analysis of adhesion between cement and bamboo by pull-off tests (Fig. 6) shows that bamboo/cement have a much lower adhesion than steel rebar/cement and that adhesion results are influence by node presence [48]. This author suggests that bamboo rebar should previously be submitted to thermal treatment to improve adhesion strength. According to Mesquita et al. [49] the adhesion strength of bamboo is 70\% of smooth steel adhesion strength when a $35 \mathrm{MPa}$ concrete is used. However the adhesion strength of bamboo is almost $90 \%$ of smooth steel adhesion strength when a $15 \mathrm{MPa}$ concrete is used. These authors analyzed the effect of arti- 

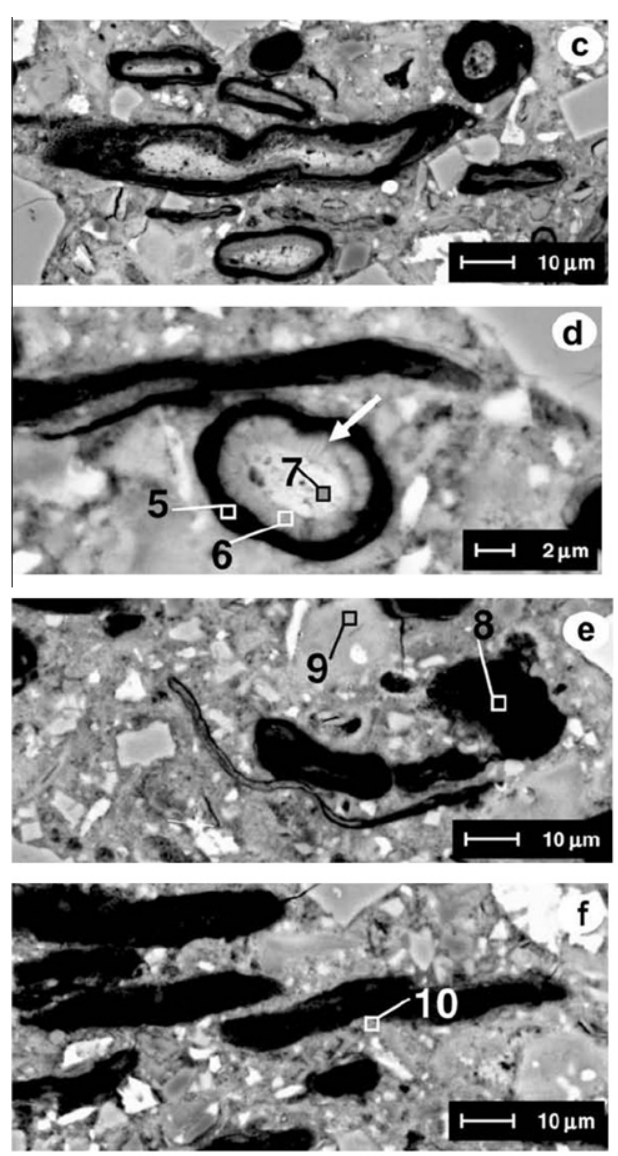
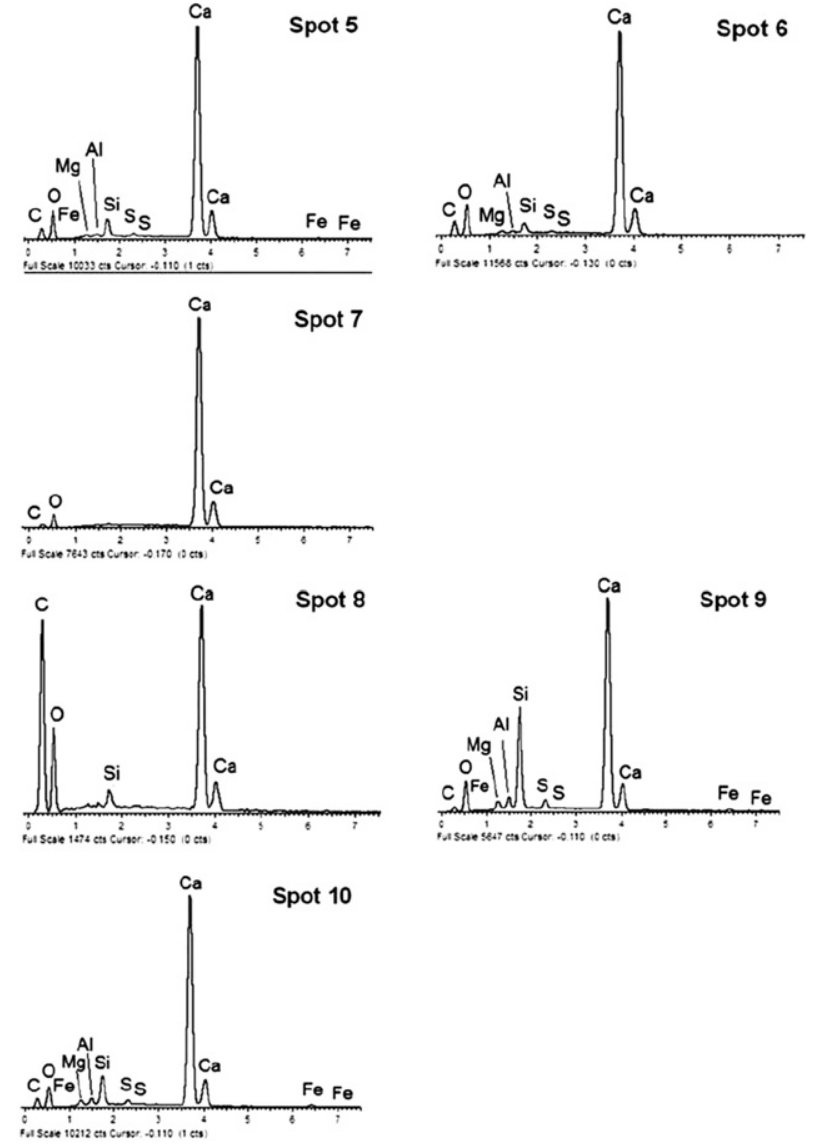

Fig. 2. SEM-BSE images of fibre cement composites obtained after 28 days of curing: (c and d) fibre modified with APTS; (e and f) (fibre modified with MPTS [34]).

ficial two pins (two of bamboo and two of steel) studding the bamboo splints and noticing they lead to a adhesion strength of bamboo higher than smooth steel. Ferreira [50] also study the effect of artificial pins (Fig. 7) in the adhesion strength of bamboo rebar using pull-out tests. The results show that the use of just one pin is insufficient to increase bamboo adhesion strength (Table 4). In the same work this author study several $20 \mathrm{MPa}$ concrete beams reinforced with bamboo rebar's $\left(2 \times 1 \mathrm{~cm}^{2}\right)$ and steel stirrups referred to an acceptable structural behaviour.

\section{Durability}

Durability of vegetable fibre reinforced cement composites is related to the ability to resist both external (temperature and humidity variations, sulphate or chloride attack, etc.) and internal damage (compatibility between fibres and cement matrix, volumetric changes, etc.). The degradation of natural fibres immersed in Portland cement is due to the high alkaline environment which dissolves the lignin and hemicellulose phases, thus weakening the fibre structure [51]. Gram was the first author to study the durability of sisal and coir fibre reinforced concrete. The fibre degradation was evaluated by exposing them to alkaline solutions and then measuring the variations in tensile strength. This author reported a deleterious effect of $\mathrm{Ca}^{2+}$ elements on fibre degradation. He also stated that fibres were able to preserve their flexibility and strength in areas with carbonated concrete with a $\mathrm{pH}$ of 9 or less. Toledo Filho et al. [52] also investigated the durability of sisal and coconut fibres when immersed in alkaline solutions. Sisal and coconut fibres conditioned in a sodium hydroxide solution retained respectively $72.7 \%$ and $60.9 \%$ of their initial strength after 420 days.
As for the immersion of the fibres in a calcium hydroxide solution, it was noticed that original strength was completely lost after 300 days. The explanation for the higher attack by $\mathrm{Ca}(\mathrm{OH})_{2}$ can be related to a crystallization of lime in the fibres pores. Ramakrishna and Sundararajan [53] also reported degradation of natural fibre when exposed to an alkaline medium. Other authors [54] studied date palm reinforced concrete reporting low durability performance which is related to fibre degradation when immersed in alkaline solutions. Vegetable fibre-cement based roofing tiles show a toughness reduction of $53 \%$ and $68 \%$ after 4 months of external weathering (Fig. 8) [55]. Ghavami [56] reported the case of a bamboo reinforced concrete beam with 15 years old and without deterioration signs. Lima et al. [57] studied the variations of tensile strength and Young's modulus of bamboo fibre reinforced concrete expose to wetting and drying cycles, reporting insignificant changes, thus confirming its durability. The capacity of natural fibres to absorb water is another way to decrease the durability of fibre reinforced concrete. Water absorption leads to volume changes that can induce concrete cracks [56,59]. Cement composites obtained by the Hatschek process show high durability for high refinement pulp sisal [59]. In order to improve the durability of fibre reinforced cement composites two following paths could be used:

\subsection{Matrix modification}

Using low alkaline concrete by adding pozzolanic by-products to Portland cement such as rice husk ash or fly ashes [58,60,61]. Results show that the use of ternary blends containing slag/ metakaolin and silica fume are effective in preventing fibre degra- 

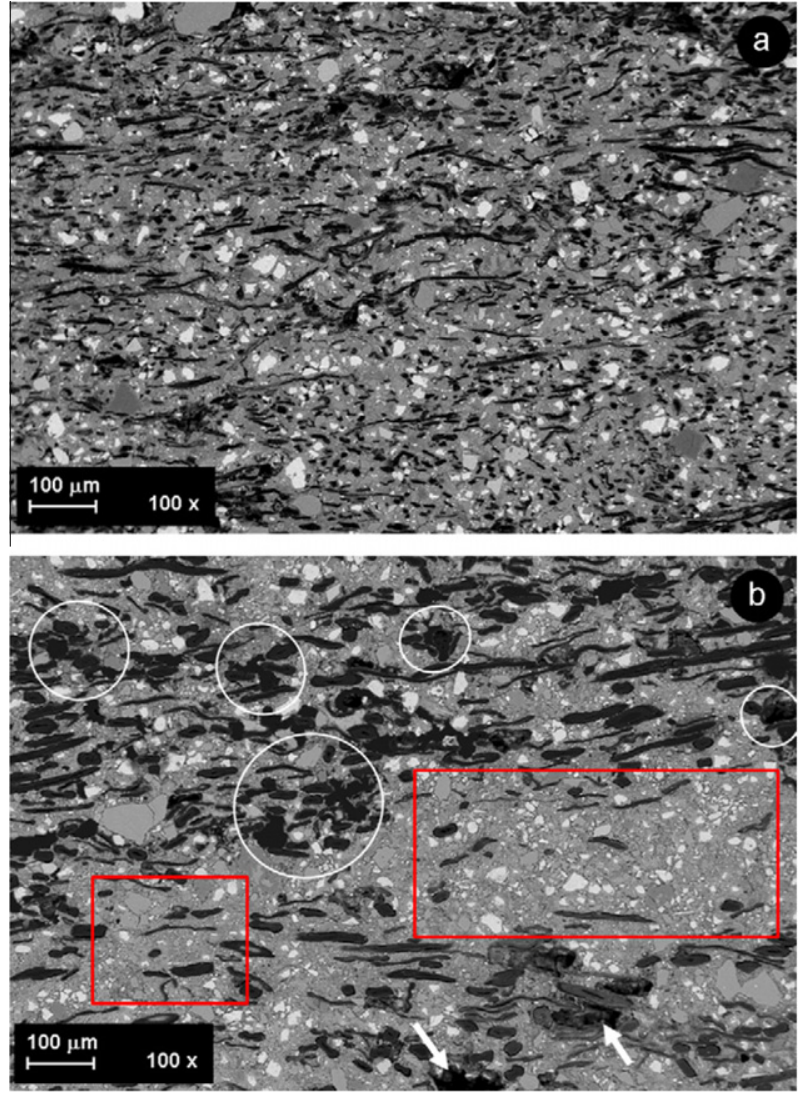

Fig. 3. SEM/BSE images of vegetable cement composites reinforced with: (a) eucalyptus pulp; (b) pinus pulp. Circles are fibres clumps or local fibre concentration and square and rectangle are fibre-free areas [45].

(a)

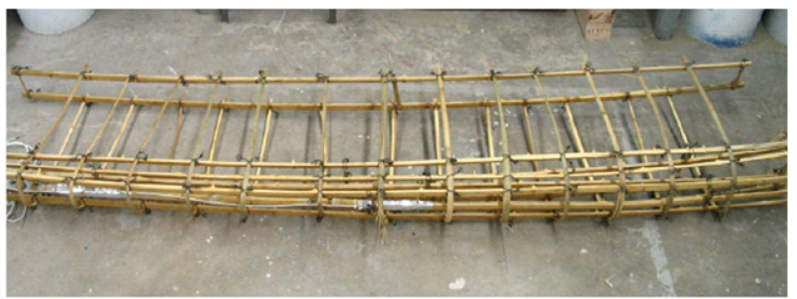

(b)

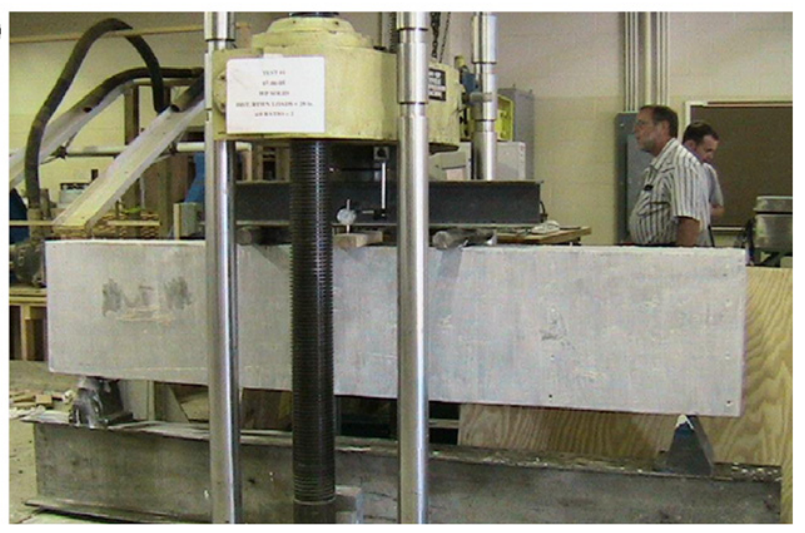

Fig. 4. Concrete beam reinforced with bamboo rebars: (a) finished reinforcement (b) test set-up [46].

dation [62]. But in some cases the low alkalinity is not enough to prevent lignin from being decomposed [13]. Also fast carbonation can induce lower alkalinity [58]. This is confirmed by others [63]

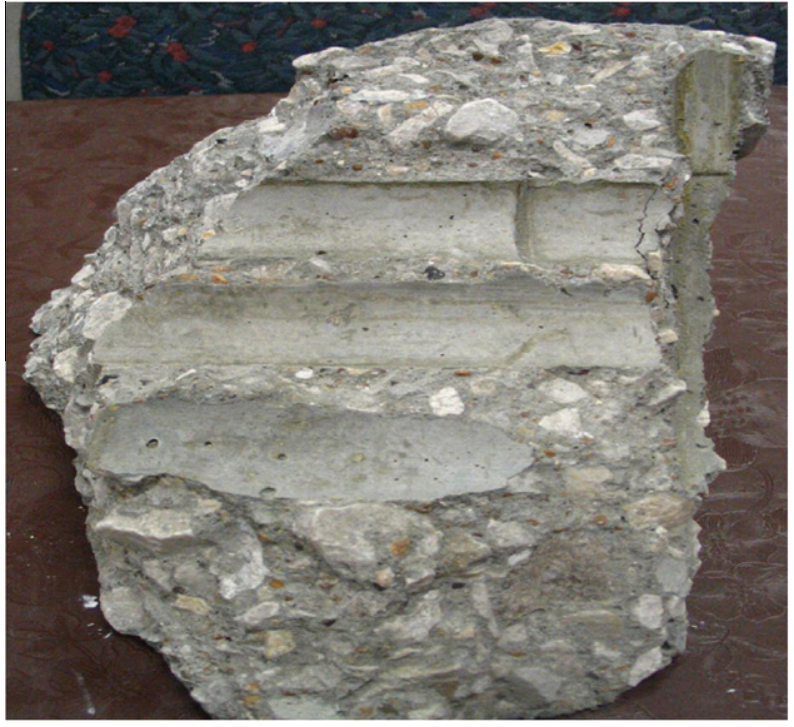

Fig. 5. Imprints of bamboo reinforcement [46].

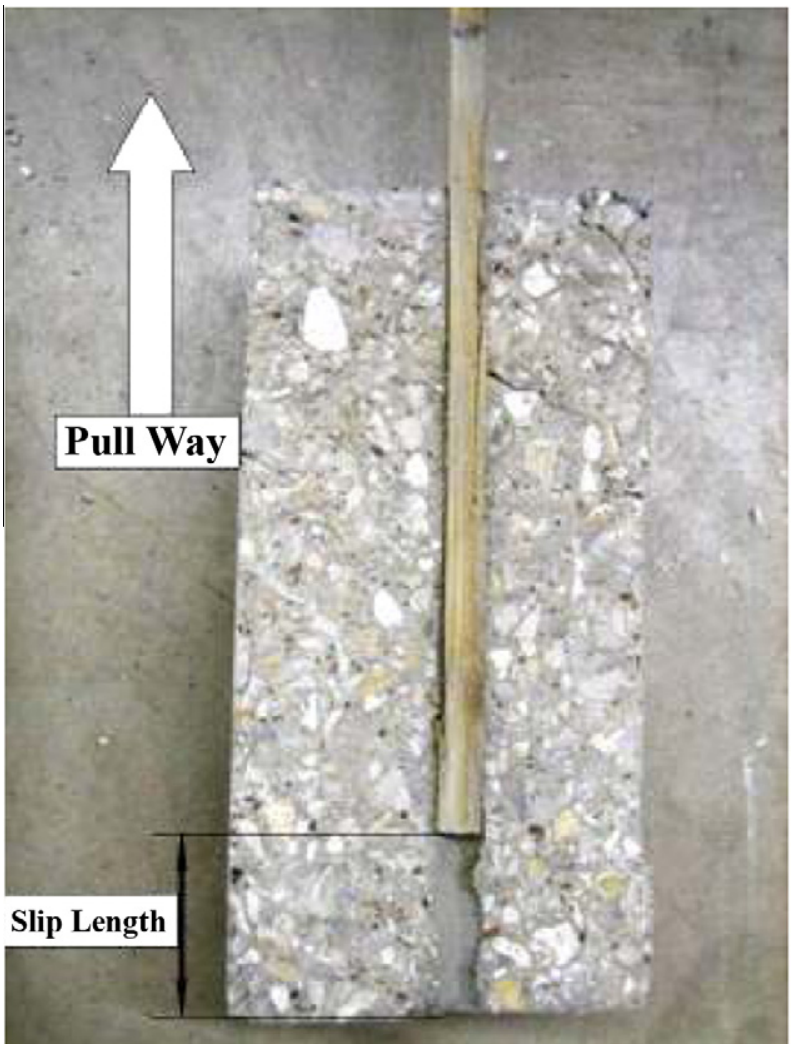

Fig. 6. Pull-out test of concrete with bamboo reinforcement [48].

that used artificial carbonation in order to obtain $\mathrm{CaCO}_{3}$ from $\mathrm{Ca}(\mathrm{OH})_{2}$ leading to an increasing strength and reduced water absorption. The use of cement based polymers can contribute to increase durability [64]. D'Almeida et al. [65] used blends where 50\% of Portland cement was replaced by metakaolin producing a matrix totally free of calcium hydroxide that prevents migration of calcium hydroxide to the fibre lumen, middle lamella and cell walls and thus avoid embrittlement behaviour. 


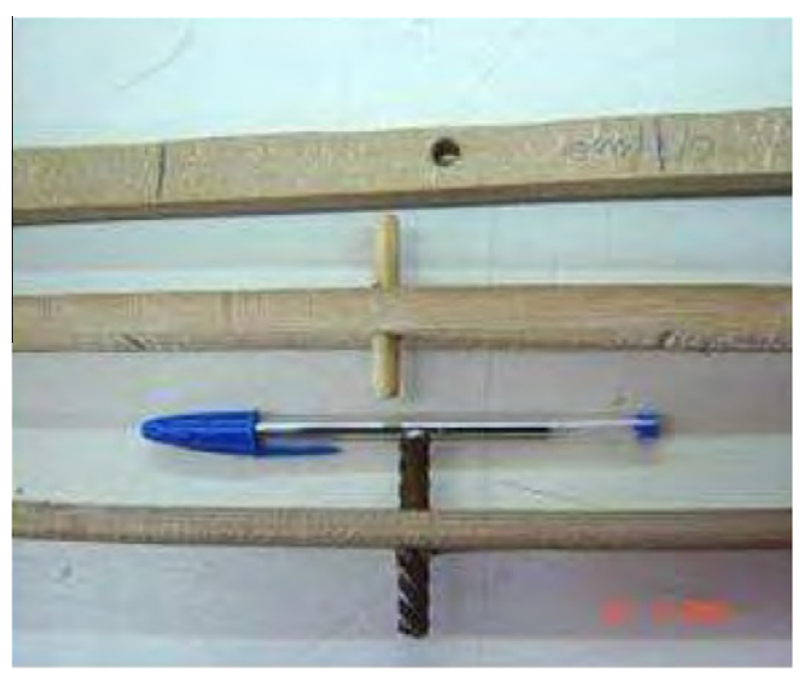

Fig. 7. Bamboo rebars bamboo and steel pins [50].

Table 4

Bond strength using pull-out tests [50]

\begin{tabular}{ll}
\hline Rebar type & Adhesion strength (MPa) \\
\hline Bamboo & 0.81 \\
Bamboo with epoxi & 0.32 \\
Bamboo with 1 bamboo pin & 0.82 \\
Bamboo with 1 steel pin & 0.69 \\
Bamboo with hole & 1.10 \\
Rough steel & 6.87 \\
Smooth steel & 1.33 \\
\hline
\end{tabular}

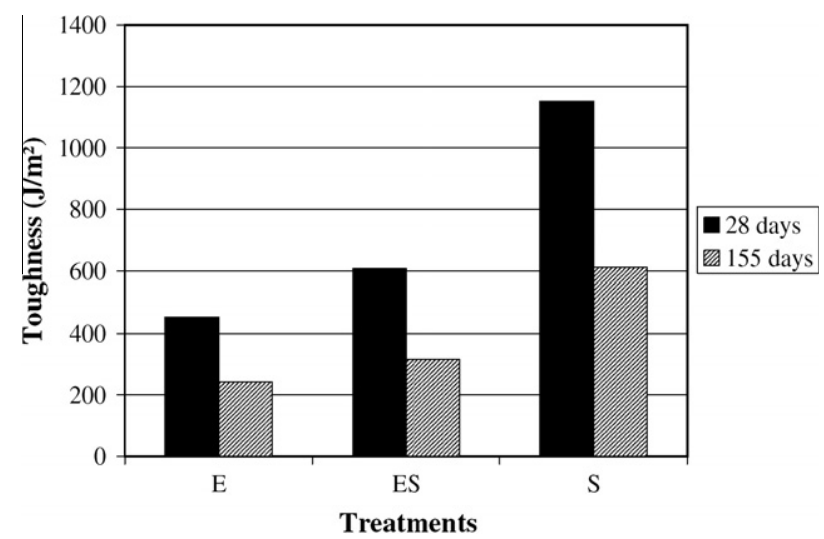

Fig. 8. Toughness of vegetable fibre cement tiles. $\mathrm{E}$ ( $5 \%$ eucaliptus); $\mathrm{S}$ ( $3 \%$ sisal); ( $1 \%$ eucaliptus, $3 \%$ sisal) [55].

\subsection{Fibre modification}

Coating natural fibres to avoid water absorption and free alkalis. Using water-repellent agents or fibre impregnation with sodium silicate, sodium sulphite, or magnesium sulphate. Ghavami [32] reported the use of a water-repellent in bamboo fibres allowed for only $4 \%$ water absorption. The use of organic compounds like vegetable oils reduced the embrittlement process, but not completely [64]. Toledo et al. recommend the immersion of the fibre in a silica fume slurry before adding it to the mix [66]. Recent findings report that a silane coating of fibres is a good way to improve the durability of natural fibre reinforced concrete [67]. Other authors mentioned that using pulped fibres can improve durability performance [68]. Some [69] even reported that the fibre extraction process can prevent durability reductions. The use of compres- sion and temperature $\left(120,160\right.$ and $\left.200{ }^{\circ} \mathrm{C}\right)$ leads to an increase of fibre stiffness and a decrease of fibre moisture absorption [70].

\section{Conclusions}

The available literature data is mostly related to the mechanical behaviour of cementitious building materials reinforced with vegetable fibres. Further investigations are needed in order to clarify several aspects that current knowledge does not. As an example only recently has the delaying effect of fibre inclusion received the proper attention. Since the main reason for fibre degradation relates to alkaline degradation, much more research is needed about the chemical interactions between the cement matrix and the natural fibres. The right treatments to improve fibre and cement matrix compatibility are still to be found. The same could be said about the variation on fibre properties thus controlling quality methods are needed in order to ensure minimal variations on the properties of natural fibres. Durability related issues also deserve further investigations. Concrete structures reinforced with bamboo fibres are a promising field towards a more sustainable construction. Long bamboo fibres present high durability when immersed in a cement matrix, nevertheless mechanical performance of bamboo reinforcement still deserve more research efforts.

\section{References}

[1] IPCC, Intergovernmental panel on climate change, climate change 4th assessment report; 2007.

[2] Stern N. Stern review on economics of climate change. Cambridge University Press; 2006.

[3] Glasser F, Marchand J, Samson E. Durability of concrete. Degradation phenomena involving detrimental chemical reactions. Cem Concr Res 2008;38:226-46.

[4] Bentur A, Mitchell D. Material performance lessons. Cem Concr Res 2008;38:259-72.

[5] Gjorv O. Steel corrosion in concrete structures exposed to Norwegian marine environment. ACI Concrete International 1994:35-9.

[6] Ferreira RM. Service-life design of concrete structures in marine environments: a probabilistic based approach. VDM Verlag Dr. Muller Aktiengesellschaft \& Co. KG; 2009 [ISBN-13: 978-3639167108].

[7] Mora E. Life cycle, sustainability and the transcendent quality of building materials. Build Environ 2007;42:1329-34

[8] Brandt A. Fibre reinforced cement-based (FRC) composites after over 40 years of development in building and civil engineering. Compos Struct 2008;86:3-9.

[9] Azuma K, Uchiyama I, Chiba Y, Okumura J. Mesothelioma risk and environmental exposure to asbestos: past and future trends in Japan. Int J Occup Environ Health 2009;15:166-72.

[10] Kumagai S, Kurumatani N. Asbestos fiber concentration in the area surrounding a former asbestos cement plant and excess mesothelioma deaths in residents. Am J Ind Med 2009;52:790-8.

[11] Ikai S, Reicher J, Rodrigues A, Zampieri V. Asbestos-free technology with new high toughness polypropylene (PP) fibers in air-cured Hatschek process. Constr Build Mater 2010;24:171-80.

[12] Berge B. The ecology of building materials. 2nd ed. Architectural Press, Elsevier; 2007 [ISBN: 978-1-85617-537-1].

[13] John V, Cincotto M, Sjotrom C, Agopyan V, Oliveira C. Durability of slag mortar reinforced with coconut fibre. Cem Concr Compos 2005;27:565-74.

[14] Arsène M-A, Savastano Jr H, Allameh SM, Ghavami K, Soboyejo W. Cementitious composites reinforced with vegetable fibers. In: Proceedings of the first interamerican conference on non-conventional materials and technologies in the eco-construction and Infrastructure. In: 13-16 November 2003, JoaoPessoa Brazil, IAC-NOCMAT 2003, proceedings, ISBN: 85-98073-02-4; 2003.

[15] Kriker A, Debicki G, Bali A, Khenfer M, Chabannet M. Mechanical properties of date palm fibres and concrete reinforced with date palm fibres in hot dry climates. Cem Concr Compos 2005;27:554-648.

[16] Passuello A, Moriconi G, Shah S. Cracking behavior of concrete with shrinkage reducing admixtures and PVA fibers. Cem Concr Compos 2009;31:699-704.

[17] Swamy R. Vegetable fibre reinforced cement composites - a false dream or a potential reality? In: Proceedings of the 2nd international symposium on vegetable plants and their fibres as building materials. Rilem Proceedings 7. Chaman and Hall; 1990, p. 3-8.

[18] Li Z, Wang X, Wang L. Properties of hemp fibre reinforced concrete composites. Composites Part A 2006;37:497-505.

[19] Savastano H, Warden P, Coutts R. Mechanically pulped sisal as reinforcement in cementitious matrices. Cem Concr Compos 2003;25:311-9.

[20] Pehanich J, Blankenhorn P, Silsbee M. Wood fiber surface treatment level effects on selected mechanical properties of wood fiber-cement composites. Cem Concr Res 2004;34:59-65. 
[21] Savastano H, Warden P, Coutts R. Performance of low-cost vegetable fibrecement composites under weathering. CIB world building congress, Wellington, New Zealand; 2001a, 11p.

[22] Castellano M, Gandini A, Fabbri P, Belgacem M. Modification of cellulose fibres with organosilanes: under what conditions does coupling occur? J Colloid Interf Sci 2004;273:505-11.

[23] Abdelmouleh M, Boufi S, Belgacem M, Duarte A, Salah A, Gandini A. Modification of cellulosic fibres with funcionalised silanes: development of surface properties. Int J Adhes Adhes 2004;24:43-54.

[24] Joaquim A, Tonoli G, Santos S, Savastano H. Sisal organosolv pulp as reinforcement for cement based composites. Mater Res 2009;12:305-14.

[25] Arsene M, Okwo A, Bilba K, Soboyejo A, Soboyejo W. Chemically and thermally treated vegetable fibers for reinforcement of cement-based composites. Mater Manuf Processes 2007;22:214-27.

[26] Savastano H, Warden P, Coutts R. Brazilian waste fibres as reinforcement for cement-based composites. Cem Concr Compos 2000;22:379-84.

[27] Bilba K, Arsene M, Ouensanga A. Sugar cane bagasse fibre reinforced cement composites. Part I. Influence of the botanical components of bagasse on the setting of bagasse/cement composite. Cem Concr Compos 2003;25:91-6.

[28] Stancato A, Burke A, Beraldo A. Mechanism of a vegetable waste composite with polymer-modified cement (VWCPMC). Cem Concr Compos 2005;27: 599-603.

[29] Sedan D, Pagnoux C, Smith A, Chotard T. Mechanical properties of hemp fibre reinforced cement: influence of the fibre/matrix interaction. J Eur Ceram 2008;28:183-92.

[30] Savastano H, Agopyan V. Transition zone studies of vegetable fibre-cement paste composites. Cem Concr Compos 1999;21:49-57.

[31] Savastano H, Warden P, Coutts R. Microstructure and mechanical properties of waste fibre-cement composites. Constr Build Mater 2005;27:583-92.

[32] Ghavami K. Ultimate load behaviour of bamboo-reinforced lightweight concrete beams. Cem Concr Compos 1995; 17:281-8.

[33] Coutts R. A review of Australian research into natural fibre cement composites Cem Concr Compos 2005;27:518-26.

[34] Tonoli G, Rodrigues Filho U, Savastano H, Bras J, Belgacem M, Lahr, et al. Cellulose modified fibres in cement based composites. Composites Part A 2009:2046-53.

[35] Filho R, Ghavami K, Sanjuán M, England G. Free, restrained and drying shrinkage of cement mortar composites reinforced with vegetable fibres. Cem Concr Compos 2005;27:537-46.

[36] Al-Oraimi S, Seibi A. Mechanical characterization and impact behavior of concrete reinforced with natural fibres. Compos Struct 1995;32:165-71.

[37] Ramakrishna G, Sundararajan T. Impact strength of a few natural fibre reinforced cement mortar slabs: a comparative study. Cem Concr Compos 2005;27:547-53.

[38] Razak A, Ferdiansyah T. Toughness characteristics of Arenga pinnata fibre concrete. J Nat Fibers 2005;2:89-103.

[39] Li Z, Wang L, Wang X. Compressive and flexural properties of hemp fiber reinforced concrete. Fibers Polym 2004;5:187-97.

[40] Reis J. Fracture and flexural characterization of natural fiber-reinforced polymer concrete. Constr Build Mater 2006;20:673-8.

[41] Li Z, Wang L, Wang X. Flexural characteristics of coir fiber reinforced cementitious composites. Fibers Polym 2004;7:286-94.

[42] Silva J, Rodrigues D, Dias. Compressive strength of low resistance concrete manufactured with sisal fiber. $51^{\circ}$ Brazilian congress of ceramics, Salvador Brazil; 2007.

[43] Savastano H, Santos S, Radonjic M, Soboyejo W. Fracture and fatigue of natural fiber-reinforced cementitious composites. Cem Concr Compos 2009;31: 232-43.

[44] Silva FD, Filho RDT, Filho JdAM, Fairbairn E. Physical and mechanical properties of durable sisal fiber-cement composites. Constr Build Mater 2010;24:777-85.

[45] Tonoli G, Savastano H, Fuente E, Negro C, Blanco A, Lahr F. Eucalyptus pulp fibres as alternative reinforcement to engineered cement-based composites. Ind Crops Prod 2010;31:225-32.
[46] Khare L. Performance evaluation of bamboo reinforced concrete beams. Master of Science in Civil Engineering, University of Texas; 2005.

[47] Júnior H, Mesquita L, Fabro G, Willrich F, Czarnieski C. Vigas de concreto reforçadas com bambu Dendrocalamus giganteus. I: analise experimental. Rev Bras de Engenharia Agrícola e Ambiental 2005;9:642-51 [in Portuguese].

[48] Jung Y. Investigation of bamboo as reinforcement in concrete. Master of Science in Civil and Environment Engineering, University of Texas; 2006.

[49] Mesquita L, Czarnieski C, Braga Filho A, Willrich F, Júnior H, Barbosa N. Determinação da tensão de aderência do bambu-concreto. Rev Bras de Engenharia Agrícola e Ambiental 2006;10:505-16 [only in Portuguese].

[50] Ferreira G. Vigas de concreto armadas com taliscas de bamboo Dendrocalamus giganteus. PhD thesis, UNICAMP, Brazil; 2007 [only in Portuguese].

[51] Gram H. Durability of natural fibres in concrete. Stockolm: Swedish Cement and Concrete Research Institute; 1983.

[52] Toledo Filho R, Scrivener K, England G, Ghavami K. Durability of alkalisensitive sisal and coconuts fibres in cement mortar composites. Cem Concr Compos 2000;22:127-43.

[53] Ramakrishna G, Sundararajan T. Studies on the durability of natural fibres and the effect of corroded fibres on the strength of mortar. Cem Concr Compos 2005;27:575-82.

[54] Kriker A, Bali A, Debicki G, Bouziane M, Chabannet M. Durability of date palm fibres and their use as reinforcement in hot dry climates. Cem Concr Compos 2008;30:639-48.

[55] Roma L, Martello L, Savastano H. Evaluation of mechanical, physical and thermal performance of cement-based tiles reinforced with vegetable fibers. Constr Build Mater 2008;22:668-74.

[56] Ghavami K. Bamboo as reinforcement in structure concrete elements. Cem Concr Compos 2005;27:637-49.

[57] Lima H, Willrich F, Barbosa N, Rosa M, Cunha B. Durability analysis of bamboo as concrete reinforcement. Mater Struct 2008;41:981-9.

[58] Agopyan V, Savastano H, John V, Cincotto M. Developments on vegetable fibre-cement based materials in São Paulo, Brazil: an overview. Cem Concr Compos 2005;27:527-36.

[59] Tonoli G, Joaquim A, Arsne M, Bilba K, Savastano H. Performance and durability of cement based composites reinforced with refined sisal pulp. Mater Manuf Process 2007;22:149-56.

[60] Gutiérrez R, Díaz L, Delvasto S. Effect of pozzolans on the performance of fiberreinforced mortars. Cem Concr Compos 2005;27:593-8.

[61] Savastano H, Warden P, Coutts R. Potential of alternative fibre cements as building materials for developing areas. Cem Concr Compos 2005;25:585-92.

[62] Mohr B, Biernacki J, Kurtis K. Supplementary cementitious materials for mitigating degradation of kraft pulp fiber cement-composites. Cem Concr Res 2007;37:1531-43.

[63] Tonoli G, Santos S, Joaquim A, Savastano H. Effect of accelerated carbonation on cementitious roofing tiles reinforced with lignocellulosic fibre. Constr Build Mater 2010;24:193-201.

[64] Pimentel L, Beraldo A, Savastano H. Durability of cellulose-cement composites modified by polymer. Eng Agr 2006;26:344-53.

[65] D’Almeida A, Melo Filho J, Toledo Filho R. Use of curaua fibers as reinforcement in cement composites. Chem Eng Trans 2009;17:1717-22.

[66] Toledo R, Ghavami K, England G, Scrivener K. Development of vegetable fibremortar composites of improved durability. Cem Concr Compos 2003;25:185-96.

[67] Bilba K, Arsene M. Silane treatment of bagasse fiber for reinforcement of cementitious composites. Composites Part A 2008;39:1488-95.

[68] Savastano H, Warden P, Coutts R. Ground iron blast furnace slag as a matrix for cellulose-cement materials. Cem Concr Compos 2001;23:389-97.

[69] Juárez C, Durán A, Valdez P, Fajardo G. Performance of "Agave lechuguilla" natural fiber in Portland cement composites exposed to severe environment conditions. Build Environ 2007;42:1151-7.

[70] Motta L, John V, Agopyan V. Thermo-mechanical treatment to improve properties of sisal fibres for composites. In: 5th international materials symposium MATERIALS 2009 - 14th meeting of SPM - Sociedade Portuguesa de Materiais, Lisbon; 2009. 